\title{
Payroll Taxes and Firm Performance
}

Niklas Kaunitz and Johan Egebark 


\title{
Payroll Taxes and Firm Performance*
}

\author{
Niklas Kaunitz ${ }^{\dagger} \quad$ Johan Egebark E $^{\ddagger}$
}

April 8, 2018

\begin{abstract}
The Swedish employer paid payroll tax was reduced substantially for young workers in 2007, causing firms' average social fees to depend on the age structure of their employees. Using pre-reform conditions to define treated and control firms, we show that the lower costs induced by the reduced taxes have no impact on exit rates or profitability. We find negligible effects on gross investments, and negative, but not statistically significant, effects on labor productivity.
\end{abstract}

Keywords: Payroll taxes, labor costs, profitability, labor productivity, investments, windfall gain, tax subsidy, firm survival

JEL codes: D22, H22, J38, L25

${ }^{*}$ We thank Louise Johannesson, Matthew Lindquist, Erik Lindqvist and Markus Jäntti for helpful comments. Financial support from IFAU, Uppsala, and the Jan Wallander and Tom Hedelius Foundation is gratefully acknowledged.

${ }^{\dagger}$ Corresponding author. Swedish Institute for Social Research (SOFI), Stockholm University. E-mail: niklas.kaunitz@sofi.su.se

${ }^{\ddagger}$ Research Institute of Industrial Economics (IFN), Stockholm, Sweden. E-mail: johan.egebark@ifn.se 


\section{Introduction}

How do sudden labor cost reductions affect firm performance? We answer this question by exploring a tax reform implemented in Sweden in 2007, which substantially reduced the employer-paid payroll tax for young workers. In 2007, in an attempt to stimulate hiring

of young workers, the Swedish government lowered the payroll tax rate for employers of workers aged 19-25. Consequently, after 2007, the tax rate faced by a firm came to depend on the age composition of its employees. This provides a testing ground for examining how firms react to a sudden shock in labor costs, and, since many factors of production are fixed in the very short run, how firms respond to government-induced cash windfalls.

By using pre-reform conditions, i.e. the age structure in 2006, we study the causal effects of a sudden cost reduction on several different firm performance measures, including profits, productivity and investments. We first show that exit rates were unaffected by the lower payroll taxes. The zero effect on exits is fundamental for interpreting the estimates for the other measures, in order to rule out compositional bias. Furthermore, we show that profitability was completely unaffected in the first two years following the reform. Using quantile regressions, we can confirm that this holds for both high- and low-profit firms, implying that not even financially distressed firms were helped by the cash windfall. We estimate a negative effect on labor productivity, in line with standard economic theory, but this effect is not statistically significant. We find no effect on firm investments, which can perhaps be explained by the short time period under study.

The literature on how firms respond to changes in the cost of labor has evolved rapidly in recent years. A broader interest in the question came as a reaction to the voluminous empirical literature on the link between minimum wages and employment. In particular, researchers wanted to understand better why the measured employment effects of minimum- 
wage increases are so consistently small. ${ }^{1}$ The summary in Schmitt (2013) of the evidence for the U.S. concludes that the most important channels of adjustment following higher minimum wages are: reductions in labor turnover, improvements in organizational efficiency, reductions in wages for high income earners ("wage compression"), and price increases. ${ }^{2}$ While price increases are often seen as the most expected adjustment, the evidence typically finds that the effects, while being significant, are small. The National Minimum Wage (NMW), implemented in the U.K. in 1999, raised wages for low-paid British workers substantially, and has thus been used to study how higher labor costs affect firms. Metcalf (2008) summarizes the evidence from the first seven years after the implementation and concludes that the most probable adjustment channels are: profits (see Draca et al. 2011), productivity (see, e.g., Arulampalam et al. 2004 and Galindo-Rueda and Pereira 2004), and prices (Wadsworth 2010). Moreover, Arulampalam et al. (2004) studies whether the higher minimum wage in the U.K. affected labor productivity by explicitly looking at the effect on work-related training (for low-wage workers). Using Difference-in-Differences for years 1998-2000, they find no evidence that the introduction of the minimum wage reduced the training of affected workers (and some evidence that it increased it).

Our study is related to the previous evidence on firm response to cost changes. However, instead of looking at the effect of minimum wage changes, we study the impact of changes in the employer paid payroll tax. The evidence on the link between payroll taxes and firm performance is very scarce. To the best of our knowledge, there is only one other study that has looked at this link. Korkeamäki (2011) studies a payroll tax reduction -introduced in selected regions in Finland in 2003 — and finds no effect on firm profitability. Second, while

\footnotetext{
${ }^{1}$ We will not review the general literature on minimum wages here. For summaries, see e.g. Neumark and Wascher (2006).

${ }^{2}$ Schmitt (2013) lists eleven possible adjustment channels: hours worked (evidence is not conclusive), non-wage benefits such as health insurance and pensions (no effect), training (mixed results), changes in employment composition (mixed results), prices (small positive effect), efficiency (little direct evidence).
} 
most other studies explore cost increases, we study the response to cost reductions. Finally, in contrast to the majority of previous studies, we are able to examine a wide range of outcomes jointly, thereby giving a more comprehensive picture of the firm's response.

Section 2 describes the mechanics of the Swedish payroll tax reduction and its institutional setting. A theoretical framework is presented in section 3 to aid our thinking about what effects we should expect. In section 4 we discuss imperfections of our data set and how we deal with them. Section 5 lays the foundation for the results in section 6 . In the latter section we also make an attempt to validate our estimation strategy. Finally, section 7 concludes.

\section{Institutional setting}

\subsection{The 2007 and 2009 payroll tax reductions ${ }^{3}$}

On July 1, 2007, the Swedish payroll tax was cut by around 11 percentage points for individuals who at the start of the year had turned 18 but not 25 years of age. This date is first mentioned in a press release from the ministry of Finance in October 2006, and this date was confirmed when the new policy was ratified in the parliament on 15 March 2007. Figure 1 provides a graphical illustration of the changes in the tax rate: as is shown, the tax reduction was substantial as the rate fell from 32.42 to 21.32 percent. Importantly, the payroll tax reductions were automatically implemented via the tax system; this means that the employers did not have to send in an application to benefit from the lower tax rates.

On January 1, 2009, the reform was modified in two ways. First, the tax reduction was extended to encompass all individuals who at the start of the year had not yet turned 26 years of age. Second, the payroll tax reduction was increased, down to 15.52 percent. Figure 2 illustrates how different cohorts are subjected to the payroll tax reductions. In

\footnotetext{
${ }^{3}$ This section builds on Egebark and Kaunitz (2017).
} 
Figure 1: The payroll tax reductions

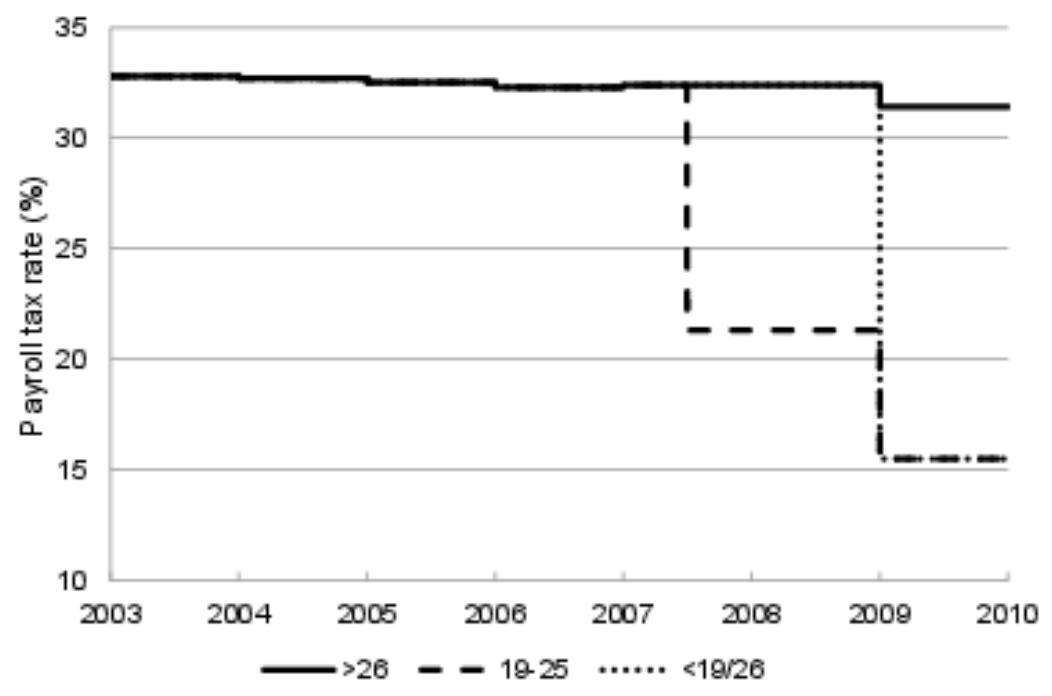

Figure 2: Evolution of treatment status across cohorts

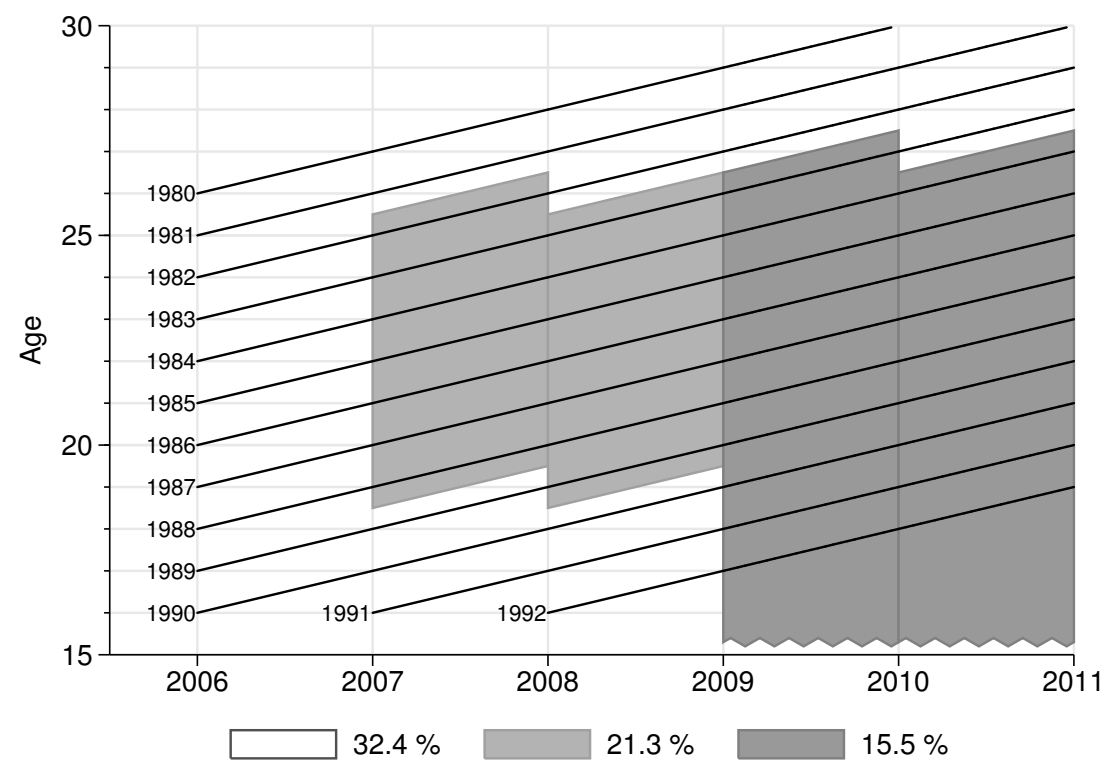


2007, the target group consists of individuals born 1982-88 whereas in 2008 it consists of those born 1983-89. The group of 19-25 year-olds comprised around 10 percent of the labor force aged 15-64 in 2007, implying that the number of individuals directly affected by the new regime was substantial.

\section{Theoretical framework}

To consider the effects of a reduction in payroll taxes for young employees, we start with considering the effects on firm profits. ${ }^{4}$ Denote the firm profit function as

$$
\Pi\left(C_{Y}, C_{O}, R, P\right)
$$

where $C_{Y}$ and $C_{O}$ are net labor costs for young and old labor, respectively, while $R$ and $P$ being remaining input and output prices. We now Taylor expand the profit function around the initial value of $C_{Y}$ (denoted $\left.C_{Y}^{0}\right)$, and then use Hotelling's lemma for the substitution $\partial \Pi / \partial C_{Y}=-L_{Y}\left(C_{Y}, C_{O}, R, P\right)$, where $L_{Y}$ is the stock of young labor:

$$
\begin{aligned}
\Pi\left(C_{Y}, \cdot\right) & \approx \Pi\left(C_{Y}^{0}, \cdot\right)+\frac{\partial \Pi}{\partial C_{Y}}\left(C_{Y}-C_{Y}^{0}\right)+\frac{1}{2} \frac{\partial^{2} \Pi}{\partial C_{Y}^{2}}\left(C_{Y}-C_{Y}^{0}\right)^{2} \\
& =\Pi\left(C_{Y}^{0}, \cdot\right)-L_{Y} \Delta C_{Y}-\frac{1}{2} \frac{\partial L_{Y}}{\partial C_{Y}}\left(\Delta C_{Y}\right)^{2}
\end{aligned}
$$

so that

$$
\Delta \Pi \approx-L_{Y} \Delta C_{Y}-\frac{1}{2} \frac{\partial L_{Y}}{\partial C_{Y}}\left(\Delta C_{Y}\right)^{2}
$$

\footnotetext{
${ }^{4}$ This gist of this derivation is similar to Draca et al. (2011).
} 
Rearranging and normalizing with net turnover,

$$
\begin{aligned}
\Delta(\Pi / T) & \approx-\underbrace{\frac{L_{Y} C_{Y}}{T}}_{\tau}[\frac{\Delta C_{Y}}{C_{Y}}+\frac{1}{2} \underbrace{\frac{C_{Y}}{L_{Y}} \frac{\partial L_{Y}}{\partial C_{Y}}}_{\eta_{Y}}\left(\frac{\Delta C_{Y}}{C_{Y}}\right)^{2}] \\
& =-\tau\left[\frac{\Delta C_{Y}}{C_{Y}}+\frac{\eta_{Y}}{2}\left(\frac{\Delta C_{Y}}{C_{Y}}\right)^{2}\right],
\end{aligned}
$$

where $\tau$ is total wagebill of young employees as a share of turnover, and $\eta_{Y}$ is the demand elasticity of young labor with respect to labor cost. Thus, the first term in the parentheses is the automatic, non-adjusting, response to the tax change, while the second term represents adjusting input factors to the new optimal allocation. ${ }^{5}$ If the degree of adaptation is negligible, the effects of the tax change on normalized profits is approximately $-\tau \frac{\Delta C_{Y}}{C_{Y}}$. In this case, $\tau$ can be interpreted as treatment intensity.

The relative sizes of the two components in equation (1) depends on the scope and speed of adjustment. We can distinguish between three cases:

1. The extreme short run: No factor adjustment at all, i.e., $\eta_{Y}=0$.

2. The short run: Labor is a variable factor, capital is fixed. $\eta_{Y}$ equals the short-run elasticity of labor demand which represents substitution between workers of different types, as well as adjusting the optimal output level.

3. The long run: All factors can be adjusted, $\eta_{Y}$ equals the long-run elasticity of labor demand.

When increasing the time horizon, the level of $\eta_{Y}$ will determine the importance of short-run adjustment. Egebark and Kaunitz (2017) estimate $\eta_{Y}$, for 2007-08 (short run), to around

\footnotetext{
${ }^{5}$ Note that with $\eta_{Y}<0$, this second term will always be negative, regardless of whether $\Delta W_{Y} \gtrless 0$. Thus, adjusting factor input to the new price vector always has a positive effect on profits, as expected.
} 
-0.3 , albeit under two strong assumptions: infinitely elastic supply of young labor, and zero demand elasticity of $L_{O}$ with respect to $C_{Y} \cdot{ }^{6}$ Taking this estimate of $\eta_{Y}$ at face value, we can use pre-reform $\tau$ as a proxy for treatment intensity, leading to an intention-to-treat (ITT) interpretation. Note that while assuming $\eta_{Y}=0$ may be reasonable for the first year or two after the tax change, this approximation is less convincing when considering a longer time span. For this reason, we will only consider short-run effects of the 2007 tax reduction.

When considering labor productivity, the short-run effects depend on the extent to which firms adapt to the new cost vector. If firms adjust their labor demand, standard microeconomic theory predicts that labor productivity should drop as a consequence. Since the profit maximizing firm equates marginal product of labor to its marginal cost, a cost reduction should lead the firm to increase its labor demand up to the point where the marginal product have dropped to the new marginal cost. Or put differently: as labor cost decreases, it becomes profitable to hire also less productive workers.

The investment decision differs from other outcomes as it is an intertemporal trade-off, and depends on expectations about future demand and price vectors. Hence, in order to properly analyze firms' investment decisions we would need to introduce a dynamic model. However, we will limit ourselves to some general observations. In the short-run, lower cost of labor is expected to increase demand for the latter, thus decreasing capital investments. However, to the extent that labor and capital are complements, lower production cost may lead to positive scale effects - i.e., the firm increases its total output. This line of reasoning suggests that capital investments could increase as a consequence of the lower payroll taxes.

\footnotetext{
${ }^{6}$ Of course, both of these assumptions are, strictly speaking, unrealistic. First, there is an ongoing debate on whether the generous welfare system in Sweden has a negative effect on labor supply. Second, the treatment and control groups used in Egebark and Kaunitz (2017) are close in age, and hence likely to be close substitutes, so the demand elasticity of $L_{O}$ w.r.t. $C_{Y}$ is likely to be positive. Hence, the reported estimate of $\eta_{Y}$ is bound to overestimate (in absolute terms) the true $\eta_{Y}$.
} 
In the end, it is, ex ante, an open question whether the short-run substition effects or the long-run scale effects dominate.

Finally, let us consider effects on $L_{Y}$ and $L_{O}$. While the labor cost decrease for young workers should (weakly) increase demand for this group, and potentially decrease demand for older workers, this is not something we can quantify with the econometric model used in this paper. As further discussed in section 5, we estimate the relative effects of previous treatment intensity. This means that we can only estimate the employment increase for firms with high $\tau$ relative to firms with low $\tau$. Hence, we, in effect, would measure how $\eta_{Y}$ and $\eta_{O}$ varies between high- and low- $\tau$ firms.

\section{Data}

\subsection{Data sources and main samples}

We use matched employer-employee data from Statistics Sweden (SCB) for the years 20032012, containing all Swedish employees, and their employers (RAMS). For each of an individual's employment spell (there are sometimes multiple of them), for each year, the original data contain start month, end month, and the total gross wage paid out from this employment source during the year. Thus, for a multiple-year spell, there is one observation for each year of the spell's duration, each with year-specific income, start month and end month (for the inner years of a spell, start and end months are given as 1 and 12, respectively). An important limitation of the data is that firms with no wage payments during the year are not included (self-employed are, however, always included, but they are not part of our estimation sample). The implications of this are discussed below.

For all firms in our sample we have firm characteristics from the Statistical Business Register (FDB), containing geographical location, industry classification, legal status and 
detailed sector affiliation, corporate form, etc. In addition, we have access to financial variables from firms' income statements for all non-financial firms (i.e., excluding banking/insurance and the entire public sector) in our population (FEK). Unfortunately, the data that Statistics Sweden provide are not the original financial statements, but "corrected" by SCB according to their mandate from the Swedish government - to provide trustworthy aggregate measures on the industry level. This includes moving financial items between firms in the same corporate groups. As a consequence, the raw observations provided in FEK, on the firm-year level, are not necessarily comparable across firms that are part of corporate groups. For this reason, we split our data into two main samples: The first sample is stand-alone firms (SA). These are Swedish-owned firms that are free from corporate group affiliation (as per an indicator variable given in FDB). This sample is further restricted to non-financial stock corporations, in order to get a more homogenous sample. The second sample consists of all corporate groups (CG). This is all firms where we have information on corporate group affiliation, aggregated on the corporate-group level. (Formally, all the Swedish corporate groups are concerns, where one of the members is the controlling firm and the rest are controlled firms.) We do not include foreign-owned firms, nor firms that are member of a foreign-owned corporate group, since we cannot trace such firms' affiliations with other foreign-owned firms. For the CG sample, financial variables such as operating profit and value-added denotes the aggregated operating profit and value-added for the whole corporate group.

\subsection{Sample selectivity}

The fact that the sample does not include firms with no wagebill has some important consequences. First, if a firm goes from a zero to positive wagebill, we may falsely classify this as firm entry (since the firm now suddenly enters our sample), and vice versa for firm 
exit. For entry, this should not be a problem, as we explicitly condition the sample on firms with at least ten employees in the initial year (further discussed below). For exit, this could lead us to overestimate firm exit. Consider a case where a firm, in the face of a major slowdown, shuts down all labor (resulting in a zero wagebill), but does not actually go into bankruptcy. We would falsely see this as a firm exit, or possibly a gap in the time series until the firm again starts incurs positive labor costs. However, our firm exit variable will still be meaningful, as long as we keep in mind that it measures shutdown of all labor, rather than a true exit from the market. Additionally, the difference-in-differences method that we use will net out bias that is symmetric across treatment and control groups, so what is discussed above is only a problem insofar as the bias differ between firms with high and low amount of young labor.

For corporate groups the consequences are potentially worse: we may lose members of a corporate group, or even the controlling firm itself if the latter is a holding company without employees. While we cannot judge the extent of the former issue, we can get an appreciation of the latter selection by studying the share of corporate groups where the controlling firm is missing in our population; this is done in subsection 4.4.

A general issue with Swedish firm-level data is that firms are identified by an organization number $(\mathrm{ON})$ that depends on the firm's legal status, i.e. whether the firm is a stock corporation, a sole proprietorship, a partnership firm, etc. Thus, firms that switch legal status are assigned a new organization number, and, as a consequence, in the data a switch appear as if the first firm terminates and a new firm simultaneously starts. This problem is arguably greatest for small firms, as most firms gravitate towards stock corporations as they grow (see Table 1 below). For this reason, we only consider firms and corporate groups with at least ten full-time equivalent employees in the year prior the the tax reduction. (As discussed above, this should also alleviate the problem with firm exit mismeasurement.) 
Furthermore, the problem of firms switching organization number should only pertain to the sample of stand-alone firms, since for our CG sample all subsidiary firms are already aggregated on the corporate-group level, and the controlling firms in the private sector are almost exclusively stock corporations. ${ }^{7}$

\subsection{Calculating treatment intensity and firm size}

As motivated in section 3, and further discussed in section 5, we use the sum of wagebill to young workers, normalized by total turnover, as a measure of treatment intensity. This is calculated in the following way.

For each firm and each employee, we have access to the annual sum of gross wage payments through the tax registers. Since we also know the birth year for all individuals, we can derive the age distribution of wage payments associated with each firm. At this point, we could simply take the sum of gross wages paid out to workers at ages 19-25 (the target group) and divide by firm turnover. However, it turns out that the sum of all received gross wages, as measures by the tax authorities (the RAMS data set), does not always equal the firm's wagebill figure given in its income statement (the FEK data set). Our solution is to use the age distribution of received gross wages to calculate the share of wages accruing to the target group, and then apply this number to the wagebill figure from the firm's income statement. The measure of treatment intensity is finally derived by normalizing with firm turnover, disregarding firms with zero or negative turnover. This measure should indicate to how large an extent a firm's costs are affected by the reduction in payroll taxes for young employees.

For calculating firm size we use the method described and applied in Egebark and Kau-

\footnotetext{
${ }^{7}$ It turns out that if we do include also the smaller firms, treatment and control groups display nonparallel historical trends, thus casting doubt on using the difference in differences method for identification. This further strengthens the case for leaving small firms out of the analysis.
} 
nitz (2017). In short, this works in the following way. We start out from a reduced sample of employed workers - the Structure of Earnings Survey - for which we have information on hours of work and contracted hourly wage. We partition this sample in cells defined by all unique combinations of age, gender, three groups of education, firm sector (local/central public, blue-collar/white-collar private), and year. For each cell, we calculate the 10th percentile of actual, full-time equivalent wage; these values are to be used as cutoff values, serving as an income criterion for full-time employment. (For the ca. 2 percent of cells with less than ten individuals we linearly impute the cutoff values using the other cells.) These monthly cutoff values are matched to the tax register data on all individuals (the RAMS data set). For each month that an individual's taxable income exceeds the appropriate cutoff value, she is, thus, classified as being full-time employed. Our employment measure uses the quarter of these income cutoffs to arrive at a measure of working at least 25 percent of full-time, for a particular month. Finally, our measure of firm size is derived by simply summing the average employment status over the year of all employment spells associated with each firm. This measure should thus be interpreted as the number of full-time, full-year equivalent employees.

\subsection{Descriptive statistics}

Tables 1-2 shows some descriptive statistics for our two main samples. There are a couple of important observations to be made. First, entry and exit is heavily correlated with firm size, for both samples. This captures two factors: firm size correlates with market entry

and exit, but also with changing legal status (which in our data appears as entry and exit). Both entry and exit seem to stabilize as firm size reach 10.

The financial variables are heavily skewed, resulting in sharp differences between the mean and the median. While the mean is seamingly erratic, the median displays patterns 
Table 1: Descriptive statistics 2006 for stand-alone firms, by firm size (percentages)

\begin{tabular}{lrrrrrr}
\hline & \multicolumn{5}{c}{ FIRM SIZE } \\
\cline { 2 - 7 } & $0-1$ & $2-4$ & $5-9$ & $10-19$ & $20-49$ & $50-499$ \\
\hline Entry & 19.3 & 6.5 & 3.5 & 2.9 & 2.5 & 4.9 \\
Exit & 16.0 & 3.9 & 2.6 & 2.0 & 2.0 & 1.0 \\
Operating profit margin, mn & -31.3 & 0.3 & -2.7 & -3.8 & 2.8 & 4.5 \\
$\quad$ (median) & 4.6 & 3.6 & 3.3 & 3.4 & 3.4 & 3.4 \\
Value added/empl. (K SEK), mn & 644.3 & 414.6 & 394.6 & 401.0 & 399.8 & 375.7 \\
$\quad$ (median) & 440.0 & 363.5 & 362.1 & 373.2 & 372.6 & 341.4 \\
Gr. inv./turnover, mn & 37.6 & 12.8 & 8.2 & 5.8 & 4.9 & 4.0 \\
$\quad$ (median) & 1.0 & 1.0 & 1.1 & 1.3 & 1.3 & 1.2 \\
Soc. fees/empl. (K SEK), mn & 134.4 & 91.4 & 87.6 & 91.1 & 90.8 & 87.8 \\
$\quad$ (median) & 89.0 & 77.8 & 80.5 & 85.6 & 86.8 & 78.6 \\
Share gr. wages 19-25, mn & 4.3 & 7.6 & 12.8 & 14.5 & 15.9 & 17.5 \\
$\quad$ (median) & 0.0 & 0.0 & 7.9 & 11.0 & 12.9 & 13.9 \\
Treatment intensity, mn & 1.4 & 1.8 & 3.4 & 4.2 & 4.2 & 4.6 \\
$\quad$ (median) & 0.0 & 0.0 & 1.5 & 2.3 & 2.7 & 2.9 \\
Number of firms & 39,443 & 43,417 & 17,882 & 6,907 & 2,124 & 305 \\
Covered employees (year-equiv.) & 38,277 & 117,204 & 115,532 & 90,788 & 60,448 & 24,552 \\
\hline
\end{tabular}


Table 2: Descriptive statistics 2006 for corporate groups, by firm size (percentages). Financial variables and number of employees are aggregated over entire corporate group, other variables refer to the controlling firm.

\begin{tabular}{lrrrrrrr}
\hline & \multicolumn{7}{c}{ CG SIZE } \\
\cline { 2 - 7 } & $0-1$ & $2-4$ & $5-9$ & $10-19$ & $20-49$ & $50-499$ & $500+$ \\
\hline Entry & 18.9 & 8.0 & 5.9 & 5.1 & 5.0 & 4.5 & 6.3 \\
Exit & 16.9 & 7.6 & 5.4 & 6.2 & 5.0 & 2.9 & 0.0 \\
Operating profit margin, mn & -97.7 & -159.0 & -111.9 & $-1,173.3$ & -58.5 & 0.3 & 6.2 \\
$\quad$ (median) & 6.0 & 4.8 & 4.2 & 4.4 & 4.3 & 4.1 & 4.7 \\
Value added/empl. (K SEK), mn & $1,038.1$ & 624.0 & 495.5 & 566.2 & 507.3 & 552.9 & 757.9 \\
$\quad$ (median) & 498.5 & 441.0 & 429.4 & 445.2 & 451.9 & 490.1 & 600.2 \\
Gr. inv./turnover, mn & 68.6 & 57.4 & 20.1 & 98.4 & 7.3 & 7.2 & 3.3 \\
$\quad$ (median) & 1.1 & 1.4 & 1.3 & 1.3 & 1.5 & 1.7 & 1.9 \\
Soc. fees/empl. (K SEK), mn & 141.4 & 114.7 & 106.4 & 113.0 & 115.0 & 121.2 & 145.9 \\
$\quad$ (median) & 91.8 & 91.5 & 95.5 & 99.0 & 103.8 & 111.7 & 134.4 \\
Share gr. wages 19-25, mn & 3.2 & 5.1 & 8.9 & 10.4 & 10.2 & 10.6 & 9.0 \\
$\quad$ (median) & 0.0 & 0.0 & 3.0 & 6.8 & 7.1 & 7.6 & 6.7 \\
Treatment intensity, mn & 1.2 & 5.1 & 4.3 & 20.3 & 2.4 & 2.7 & 2.0 \\
$\quad$ (median) & 0.0 & 0.0 & 0.5 & 1.1 & 1.2 & 1.2 & 0.8 \\
Number of CGs & 1,282 & 2,407 & 2,187 & 2,323 & 1,992 & 1,410 & 175 \\
Covered employees (year-equiv.) & 1,285 & 6,955 & 14,860 & 32,104 & 60,626 & 181,936 & 446,723 \\
\hline
\end{tabular}


for both samples. Size is positively correlated with gross investment margin and share of young employees. The largest corporate groups stands out with considerably higher labor productivity and a somewhat higher profit margin.

\section{Identification}

We denote the ratio of firm $i$ 's total wage bill for employees aged 19-25 to net turnover by $\tau_{i}$. As argued in section 3, this number can be interpreted as normalized treatment intensity. This section discusses the econometric challenges in using empirical treatment intensity to implement the framework in section 3.

\subsection{Difference-in-differences and intention to treat}

Consider first the naïve OLS regression,

$$
y_{i, t}=\beta \tau_{i, t}+\mathbf{x}_{i, t}^{\prime} \gamma+\varepsilon_{i, t}
$$

where $y_{i, t}$ is any outcome of interest, such as profit margin, and $\mathbf{x}_{i, t}$ is a vector of firm-level control variables. There are here two major obstacles for identification: First, contemporary $\tau_{i, t}$ is not exogeneous - there is possibly a behavioral response of the reform (indeed, that was its purpose). Second, $\tau_{i, t}$ may be correlated with omitted factors that also influence the outcome, e.g. industry, local labor market, firm size etc. The former is a simultaneity problem, while the latter can be interpreted as a selection problem.

We use a difference-in-differences setup to handle the selection problem, and counter simultaneity by using the value of $\tau_{i}$ in 2006 , before any adaptation can take place. Thus, the

group of treated firms are defined as those for which $\tau_{2006}$ is above some threshold $c$. Thus, a DiD regression can be specified, under the following assumption on the counterfactual 
outcome:

$$
E\left[y_{i, t}^{0} \mid \tau_{i, 2006} \geq c\right]=E\left[y_{i, t}^{0} \mid \tau_{i, 2006}<c\right]+\alpha
$$

That is, we assume that firm outcomes across treatment and control groups would move in parallel, had there not been a change in payroll taxes. We have settled on using the threshold $c=0.1$, so that the treatment group consists of those firm which in 2006 had a wagebill sum to workers at 19-25 years of age of at least ten percent of total turnover. For the sample of stand-alone firms, the share of treated firms in 2007 is 8.5 percent, while the same figure for corporate groups is 4.1 percent (these figures are for our estimation samples, where we disregard firms for which size $<10)$. The motivation for choosing this high a cutoff (and, consequently, small treatment groups), is to ascertain that the cost reduction really bites for the treatment groups. We have done extensive robustness checks with different treatment group definitions, including having multiple treatment groups with different degrees of treatment intensity. The result of those exercises are broadly in line with the results reported in the paper.

Figures 3 and 4 plot the distribution of $\tau_{i, t}$ in 2006 for our two samples, with the cutoff $c$ marked by dashed lines. In terms of covered employees, the treatment group consists of 9.8 and 2.7 percent of all employees, in stand-alone firms and corporate groups, respectively. Median treatment intensity for treatment and control groups are 0.14 vs. 0.02 and 0.14 vs. 0.01, for stand-alone firms and corporate groups, respectively.

The fact that we fix treatment intensity in 2006 means that we estimate intention to treat (ITT), rather than the true average treatment effect. Since $\tau$ may fluctuate over time, using $\tau_{2006}$ as a predictor of $\tau_{t}$ will be increasingly noisy as $\tau$ moves away from 2006 . As a consequence, the ITT estimator will tend to underestimate the true treatment effect, and increasingly so for later years. Or put differently: each additional year from 2006 estimates the effect for an increasingly smaller subset of non-reactive firms. Table 3 shows 
Figure 3: Distribution of treatment intensity: stand-alone firms, 2006 (treatment group cutoff indicated by the dashed line)

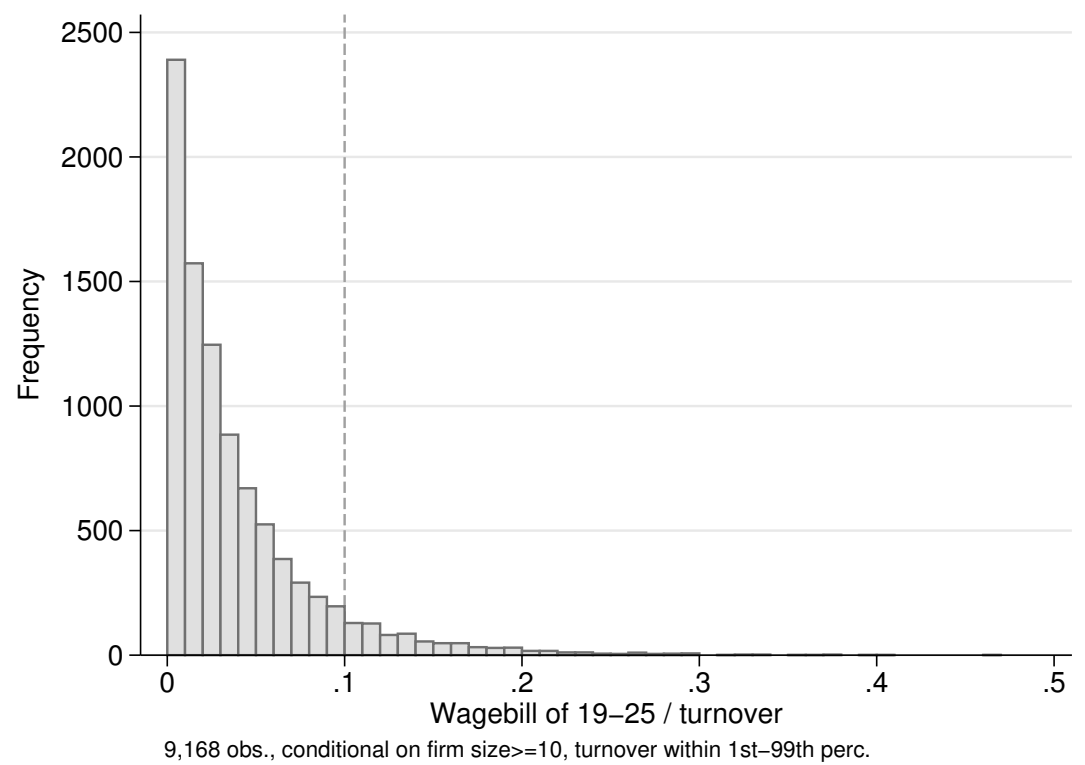

Figure 4: Distribution of treatment intensity: corporate groups, 2006 (treatment group cutoff indicated by the dashed line)

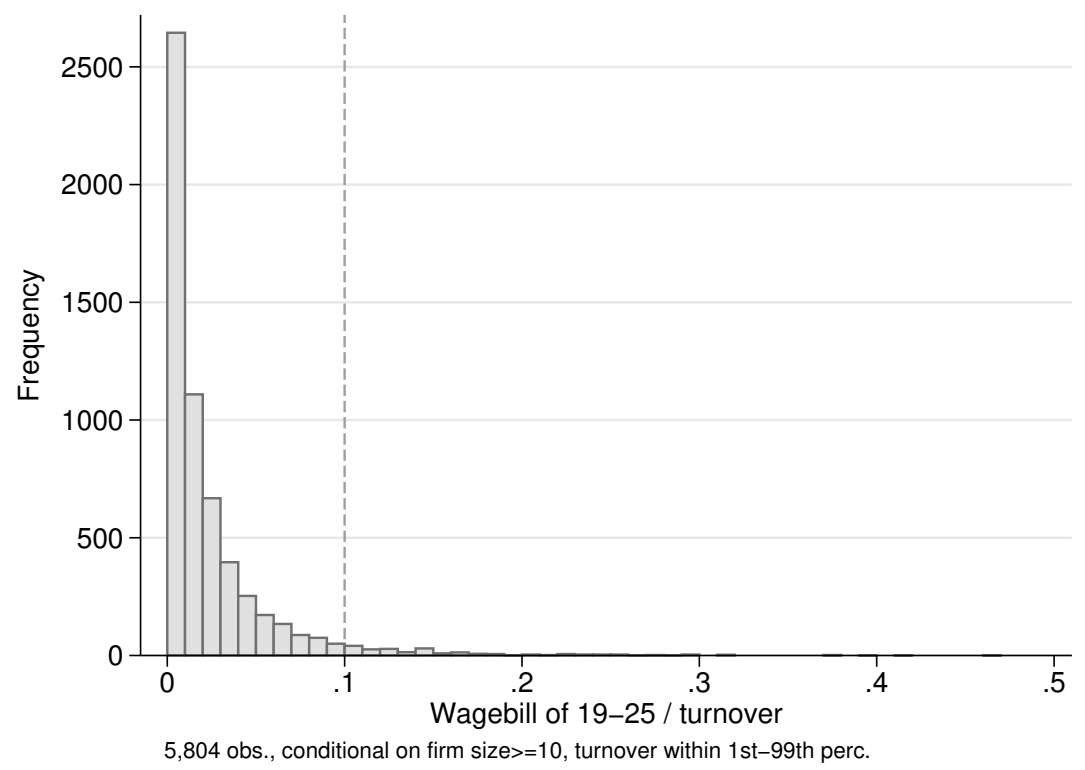


Table 3: Correlation of contemporary treatment intensity with its 2006 value

\begin{tabular}{|c|c|c|c|c|}
\hline & \multicolumn{2}{|c|}{ STAND-ALONE } & \multicolumn{2}{|c|}{ CORP. GROUPS } \\
\hline & 2007 & 2008 & 2007 & 2008 \\
\hline $0-1$ & 0.14 & 0.01 & 0.09 & 0.01 \\
\hline $2-4$ & 0.11 & 0.09 & 0.74 & 0.04 \\
\hline $5-9$ & 0.35 & 0.13 & 0.06 & 0.81 \\
\hline $10-19$ & 0.83 & 0.56 & 0.25 & 0.09 \\
\hline $20-49$ & 0.88 & 0.81 & 0.89 & 0.69 \\
\hline 50-499 & 0.93 & 0.87 & 0.48 & 0.42 \\
\hline $500+$ & & . & 0.99 & 0.97 \\
\hline
\end{tabular}

Notes: The cells are $\operatorname{cor}\left(\tau_{t}, \tau_{2006}\right)$, conditional on sample and size group in 2006

how treatment intensity in 2006 is correlated with treatment intensity in 2007 and 2008, conditional on pre-reform size and sample. For firms with at least ten employees, lagged treatment intensity is a good short-run predictor, albeit better for stand-alone firms than for corporate groups.

For the financial variables, the distributions across firms are highly skewed. For this reason, we estimate effects on financial outcomes using quantile regression at three different quantiles (0.1, 0.5 and 0.9). Additionally, we provide a standard OLS estimator with firmfixed effects. However, our emphasis will be on the median regression, i.e. the ITT estimator for the firms at the median level of the outcome variable.

\subsection{Selection on firm survival}

In general, any panel of firms is subjected to selection on firm survival. One way to cope with this is simply to keep only firms alive in the entire period of study. We have instead chosen to make only the minimal requirement of being alive in 2006 and 2007. Thus, the estimates for 2007 are conditional on firms being alive up to 2007, and estimates for 2008 
are conditional on the further assumption of also surviving up to 2008. Thus, the 2007 and 2008 estimates are not directly comparable as they are conditional on different sample selections.

Because of these considerations, our first objective will be to estimate effects on firm exit. If there are such effects, this means that our estimates of financial outcomes suffer from endogenous selection bias. (If there are no exit effects, we still have selection bias, as discussed in the previous paragraph, but it is not endogenous to the tax reduction.)

\section{Results}

\subsection{Main results}

All specifications in this section estimate intention-to-treat (ITT) estimates, using firm treatment intensity in reference year (mostly 2006). However, we have also run regressions where we use 2005 as the reference year, for testing the identifying assumption of parallel counterfactual trends. These results can be found in the appendix tables A.1-A.4. A significant estimate for 2006 in these regressions would raise doubt on the validity of the identifying assumption. All regressions include a rich set of control variables capturing each firm's state in 2006 (or 2005, for regressions using 2005 as the reference year).

We start by looking at firm exit, since this is not only interesting in itself, but of crucial importance for assessing whether regressions for other outcomes may suffer from endogenous sample selection. Table 4 shows regressions for stand-alone firms (SA) and corporate groups (CG), both with 2006 and 2005 as the reference year. Intuitively, we would expect that the lower labor cost for the treated firms would lower their probability to exit. However, we need to bear in mind that our sample excludes the smallest entities where exit (and entry) is more likely to be affected. Hence, it is not obvious that we should expect a treatment 
Table 4: Firm exit (OLS regressions of intention to treat, using treatment intensity in the reference year)

\begin{tabular}{|c|c|c|c|c|}
\hline & \multicolumn{2}{|c|}{ REF. YEAR 2006} & \multicolumn{2}{|c|}{ REF. YEAR 2005} \\
\hline & $\mathrm{SA}$ & $\mathrm{CG}$ & $\mathrm{SA}$ & $\mathrm{CG}$ \\
\hline DD 2006 & & & $\begin{array}{c}0.039^{* * *} \\
(0.011)\end{array}$ & $\begin{array}{c}0.016 \\
(0.021)\end{array}$ \\
\hline DD 2007 & $\begin{array}{l}0.0061 \\
(0.010)\end{array}$ & $\begin{array}{l}0.0073 \\
(0.024)\end{array}$ & $\begin{array}{l}0.020^{*} \\
(0.010)\end{array}$ & $\begin{array}{c}0.033 \\
(0.023)\end{array}$ \\
\hline DD 2008 & $\begin{array}{l}0.021 \\
(0.011)\end{array}$ & $\begin{array}{c}0.019 \\
(0.026)\end{array}$ & $\begin{array}{l}0.027^{*} \\
(0.011)\end{array}$ & $\begin{array}{c}0.015 \\
(0.022)\end{array}$ \\
\hline$R^{2}$ & 0.02 & 0.01 & 0.02 & 0.01 \\
\hline $\mathrm{N}$ & 26,461 & 16,123 & 32,562 & 20,354 \\
\hline
\end{tabular}

effect for this margin. As seen in columns 1-2, there is no evidence that the 2007 payroll tax reduction affected firm survival for firms with at least ten employees, at least not in the first two years following the new regime. The DiD estimates are insignificant and small in magnitude, suggesting that exits are equally common across treated and untreated firms in the after-period. Columns 3-4 performs the same exercise, but using 2005 as the reference year. This is a way of validating our evaluation method, since we can here estimate placebo treatment effects 2006 - the year prior to the tax reduction. While the results for corporate groups are similar, for stand-alone firms the placebo regression indicates that the control group is not valid when using treatment intensity in 2005. This raises some concern for the credibility of our estimates for stand-alone firms - for exits as well as for other outcomes. However, there is the possibility that the year 2005 is contaminated by the fact that this year was at the bottom of the recession preceeding the 2007-08 boom (see figure 5, chapter 1). For the upcoming analysis of firm performance measures, the most important factor is that treatment and control firms do not exhibit different exit propensities in 2007-08, 
Table 5: Operating profit by turnover (intention to treat, using treatment intensity in 2006)

\begin{tabular}{|c|c|c|c|c|c|c|}
\hline & \multicolumn{3}{|c|}{ STAND-ALONE } & \multicolumn{3}{|c|}{ Corp. Groups } \\
\hline & $q=0.1$ & $q=0.5$ & $q=0.9$ & $q=0.1$ & $q=0.5$ & $q=0.9$ \\
\hline DD 2007 & $\begin{array}{c}0.008 \\
(0.010)\end{array}$ & $\begin{array}{c}0.004 \\
(0.004)\end{array}$ & $\begin{array}{c}0.005 \\
(0.010)\end{array}$ & $\begin{array}{c}-0.033 \\
(0.050)\end{array}$ & $\begin{array}{c}0.012 \\
(0.013)\end{array}$ & $\begin{array}{c}0.022 \\
(0.036)\end{array}$ \\
\hline DD 2008 & $\begin{array}{c}-0.001 \\
(0.010)\end{array}$ & $\begin{array}{c}0.001 \\
(0.004)\end{array}$ & $\begin{array}{c}0.014 \\
(0.010)\end{array}$ & $\begin{array}{c}-0.003 \\
(0.051)\end{array}$ & $\begin{array}{c}0.003 \\
(0.014)\end{array}$ & $\begin{array}{c}0.046 \\
(0.037)\end{array}$ \\
\hline$R^{2}$ & 0.06 & 0.06 & 0.27 & 0.47 & 0.01 & 0.03 \\
\hline $\mathrm{N}$ & 26,628 & 26,628 & 26,628 & 16,412 & 16,412 & 16,412 \\
\hline$y_{q}$ & -0.016 & 0.037 & 0.140 & -0.029 & 0.045 & 0.168 \\
\hline
\end{tabular}

conditional on treatment intensity in $2006 .^{8}$ The null effect on firm exit is also important in itself, as it suggests that targeted labor cost reductions do not affect short-run firm survival for somewhat larger firms. Nonetheless, since the placebo regression for stand-alone firms raises questions, we remain agnostic on whether firm survival was affected by the reduction in payroll taxes.

In table 5 we turn to firm profitability. The outcome variable is operating profits, normalized by turnover. Irrespective of which sample we use, there is no evidence that the tax reductions caused higher profits. (We have also tested changing the size cut-off, from 10 to 20 employees; the results are robust to this change.) Since the pre-treatment effects for 2006 are insignificant, and precisely estimated, there is support for the identifying assumption of common trends (see appendix table A.1). By running three separate quantile regressions, we test to what extent the lack of effects for operating profits depends on

\footnotetext{
${ }^{8}$ Taking the failed placebo regression for stand-alone firms more seriously, one may argue that the positive 2006 estimate indicates that there is a positive underlying bias on all treatment effects, even when using 2006 treatment intensity. If so, this would result in a upward bias on the 2007 and 2008 estimates, thus potentially explaining the lack of visible treatment effects on firm exit. If this line of reasoning is correct, then the analysis of firm performance below suffer from endogenous sample selection.
} 
Table 6: Value added per full-time equivalent employee (intention to treat, using treatment intensity in 2006)

\begin{tabular}{|c|c|c|c|c|c|c|}
\hline & \multicolumn{3}{|c|}{ STAND-ALONE } & \multicolumn{3}{|c|}{ CORP. GROUPS } \\
\hline & $q=0.1$ & $q=0.5$ & $q=0.9$ & $q=0.1$ & $q=0.5$ & $q=0.9$ \\
\hline DD 2007 & $\begin{array}{c}-12.6 \\
(8.6)\end{array}$ & $\begin{array}{l}-5.1 \\
(7.4)\end{array}$ & $\begin{array}{l}-1.7 \\
(17.7)\end{array}$ & $\begin{array}{l}-18.6 \\
(34.7)\end{array}$ & $\begin{array}{l}-8.8 \\
(19.3)\end{array}$ & $\begin{array}{c}-6.7 \\
(61.3)\end{array}$ \\
\hline DD 2008 & $\begin{array}{c}-15.2 \\
(8.7)\end{array}$ & $\begin{array}{c}-11.8 \\
(7.5)\end{array}$ & $\begin{array}{l}-10.3 \\
(17.9)\end{array}$ & $\begin{array}{l}-4.6 \\
(35.4)\end{array}$ & $\begin{array}{l}-5.6 \\
(19.7)\end{array}$ & $\begin{array}{c}-11.9 \\
(62.4)\end{array}$ \\
\hline$R^{2}$ & 0.17 & 0.24 & 0.25 & 0.08 & 0.18 & 0.24 \\
\hline $\mathrm{N}$ & 26,594 & 26,594 & 26,594 & 16,395 & 16,395 & 16,395 \\
\hline$y_{q}$ & 249.9 & 401.3 & 654.7 & 272.8 & 485.9 & 840.5 \\
\hline
\end{tabular}

the firm's underlying profitability. The fact that the zero result is independent of which quantile we study indicates that not even financially distressed firms were helped by the cash windfall. Given the analysis in section 3, the finding of no effect on profits is surprising. However, it is in line with the results in Korkeamäki (2011), who studies a payroll tax reform introduced in selected regions in Finland in 2003. We can thus confirm the absence of profit effects found in earlier work.

Next, we look at labor productivity, in terms of value added per full-time equivalent employee. If labor demand did increase as a response to the payroll tax reduction - and Egebark and Kaunitz (2013) show that it did - the standard model of the firm would predict that labor productivity decreases. Table 6 indicates that this may have been the case, although the estimates are noisy and not statistically significant.

Finally, table 7 report the results for gross investments. For both samples and all quantiles, the estimates are indistinguishable from zero. (For stand-alone firms, there are technically significant effects at $q=0.1$, but at infinitesimal magnitudes.) This may depend 
Table 7: Gross investments by turnover (intention to treat, using treatment intensity in 2006)

\begin{tabular}{|c|c|c|c|c|c|c|}
\hline & \multicolumn{3}{|c|}{ STAND-ALONE } & \multicolumn{3}{|c|}{ CORP. GROUPS } \\
\hline & $q=0.1$ & $q=0.5$ & $q=0.9$ & $q=0.1$ & $q=0.5$ & $q=0.9$ \\
\hline DD 2007 & $\begin{array}{l}0.000^{*} \\
(0.000)\end{array}$ & $\begin{array}{c}0.001 \\
(0.003)\end{array}$ & $\begin{array}{c}-0.002 \\
(0.016)\end{array}$ & $\begin{array}{c}0.001 \\
(0.001)\end{array}$ & $\begin{array}{c}0.001 \\
(0.007)\end{array}$ & $\begin{array}{c}0.127 \\
(0.131)\end{array}$ \\
\hline DD 2008 & $\begin{array}{l}0.000^{*} \\
(0.000)\end{array}$ & $\begin{array}{c}-0.001 \\
(0.003)\end{array}$ & $\begin{array}{c}0.002 \\
(0.017)\end{array}$ & $\begin{array}{c}0.001 \\
(0.001)\end{array}$ & $\begin{array}{c}0.003 \\
(0.007)\end{array}$ & $\begin{array}{c}0.123 \\
(0.134)\end{array}$ \\
\hline$R^{2}$ & 0.00 & 0.09 & 0.29 & 0.00 & 0.00 & 0.25 \\
\hline $\mathrm{N}$ & 26,447 & 26,447 & 26,447 & 16,412 & 16,412 & 16,412 \\
\hline$y_{q}$ & 0.000 & 0.012 & 0.149 & 0.001 & 0.016 & 0.137 \\
\hline
\end{tabular}

on uncertainty about whether the reduction would last. We would not expect firms to adjust investment decisions if they consider the new price vector to be only temporary.

The results reported in this section are robust to a number of measures. Regressions for financial outcomes have been tested also using OLS with firm-fixed effects, giving results that are qualitatively similar to those reported above, albeit considerably noisier. We have also run extensive testing with different treatment intensity cutoffs when defining the treatment group, with broadly the similar results. Finally, for profits we have tested different profit accounting items, such as profit after financial items, and profit after taxes. We have also ascertained that the null result for profit is not because of accounting tricks, such as higher appropriations or withheld reserves.

\subsection{Verifying that the treatment group is in fact treated}

In this subsection we want to verify that our treatment group definition actually captures what we want. The treatment group should get a windfall gain in terms of reduced social 
Table 8: Verifying treatment definition: social fees (thousands of SEK) per full-time equivalent employee (intention to treat, using treatment intensity in 2006)

\begin{tabular}{|c|c|c|c|c|c|c|}
\hline & \multicolumn{3}{|c|}{ StAND-ALOne } & \multicolumn{3}{|c|}{ CORP. GROUPS } \\
\hline & $q=0.1$ & $q=0.5$ & $q=0.9$ & $q=0.1$ & $q=0.5$ & $q=0.9$ \\
\hline DD 2007 & $\begin{array}{c}-4.4^{*} \\
(1.7)\end{array}$ & $\begin{array}{c}-3.2^{*} \\
(1.6)\end{array}$ & $\begin{array}{l}-2.7 \\
(3.6)\end{array}$ & $\begin{array}{l}-5.5 \\
(4.6)\end{array}$ & $\begin{array}{l}-4.4 \\
(3.8)\end{array}$ & $\begin{array}{c}-12.1 \\
(9.1)\end{array}$ \\
\hline DD 2008 & $\begin{array}{c}-8.1^{* * * *} \\
(1.7)\end{array}$ & $\begin{array}{c}-4.6^{* *} \\
(1.6)\end{array}$ & $\begin{array}{l}-2.6 \\
(3.7)\end{array}$ & $\begin{array}{c}-10.3^{*} \\
(4.7)\end{array}$ & $\begin{array}{c}-9.4^{*} \\
(3.8)\end{array}$ & $\begin{array}{c}-5.8 \\
(9.2)\end{array}$ \\
\hline$R^{2}$ & 0.19 & 0.24 & 0.28 & 0.19 & 0.28 & 0.33 \\
\hline $\mathrm{N}$ & 26,594 & 26,594 & 26,594 & 16,395 & 16,395 & 16,395 \\
\hline$y_{q}$ & 60.2 & 93.6 & 141.7 & 69.5 & 112.4 & 190.8 \\
\hline
\end{tabular}

security contributions, relative to the control group. This relies on the assumption that labor adjustment is slow enough so that firms' age structure of employees in 2006 is a good predictor for the corresponding figure in 2007-08.

Table 8 reports the result of estimating the treatment effect on average social fees paid per full-time equivalent employee. "Social fees" includes all additional labor costs beyond the gross wagebill, from union-negotiated pension plans to CEO pension payments. For the median stand-alone firm, with an average of ca. 93,000 SEK in social fees per employee and year (see bottom row of table), the relative cost decrease amounted to 3.2-4.5 thousand SEK per employee and year (taken as average over all employees). Consequently, the treatment group, as we define it, did experience a reduction in average social fees paid per full-time equivalent employee. For corporate groups the figures are similar, but considerably more noisy. This is likely to be related to the fact that treatment intensity is more stable over time for stand-alone firms than for for corporate groups, as demonstrated in table 3. Appendix table A.4 confirms that this reduction came suddenly in 2007. 


\section{Conclusions}

We have shown that, under a payroll tax reduction scheme which lowered labor costs for young workers, firm exit and profit were not affected. This is contrary to the ex ante belief, where we would expect a profit boost for firms with a large share of young workers. The null effect for profits is shown to hold both for low- and high-profit firms. Although we find indications of a decrease in labor productivity, the estimates are noisy and not statistically significant. As expected, there is no discernable effect on capital formation in the very short run.Given these results, the question arises what really became of the firm subsidies. It is shown in Egebark and Kaunitz (2017) that both employment rate and wages rose for young workers, but the obtained magnitudes do not account for the entire cost reduction. If the remaining share was not passed on to profits, where did it go?

First, Egebark and Kaunitz (2017) do not account for scale effects. Thus, it is, in theory, possible that the net employment increase was considerably larger than what is estimated. However, this is unlikely to explain the small effects on profits. We may consult table 8 (page 25) for some guidance. Firms with high exposure to the cost reduction, on average, reduced their the yearly social fees per full-time equivalent employee by no more than three to ten thousand SEK per year, in comparison to low-exposure firms. This reflects the fact that even for firms with relatively many young employees, the latter group is still usually small compared to their entire labor force. This indicates that the labor cost reduction, while of importance for the individual workers, did not, in general, have a large effect on firms' finances (as also indicated by the lack of treatment effect on profit margin). ${ }^{9}$

A second possibility is that the lower labor costs induced a response in output prices.

\footnotetext{
${ }^{9}$ It would, in this context, be interesting to study the effects also on employment and output, for highrelative to low-exposure firms. Unfortunately, due to non-parallel pre-treatment trends, we cannot present credible results for these outcomes. Nonetheless, it should be noted that, while interesting in themselves, such results would measure the differences between high- and low-exposure firms, not whether both types of firms increased output or their labor stocks.
} 
If this were the case, part of the tax reduction were passed on to consumers. Such a response should be stronger in more competitive sectors, where profit margins are smaller. As a corollary, we would potentially find stronger effects on profits by looking at the less competitive sectors. Testing this hypothesis would be a possible venue for future research.

This study has a number of limitations. First, we use an intention-to-treat setup to identify the effects of the labor cost reduction. As a consequence, estimates suffers from attenuation bias, and this may possibly explain the lack of effects for profits. However, we have shown that the payroll tax reform did result in lower social fees per employee for the treatment group, so if there were treatment effects on our outcomes, we should have captured at least some of it. Second, we are only able to study the effects of the tax reduction in the very short run. The impact on profit margin and labor productivity is likely to be quite different when the long-run capital stock is adjusted to the new labor cost vector. Third, although the tax reduction per directly affected worker is high, in most firms, the average cost reduction per worker is low. Thus, a tax reduction of this sort is likely to have more impact on the individual level than on the firm level. 


\section{References}

Arulampalam, W., A. L. Booth, and M. L. Bryan (2004). Training and the new minimum wage. The Economic Journal 114(494), C87-C94.

Draca, M., S. Machin, and J. V. Reenen (2011, January). Minimum Wages and Firm Profitability. American Economic Journal: Applied Economics 3, 129-151.

Egebark, J. and N. Kaunitz (2013). Do payroll tax cuts raise youth employment? Working Paper Series 2013:27, IFAU - Institute for Evaluation of Labour Market and Education Policy.

Egebark, J. and N. Kaunitz (2017). Payroll taxes and youth labor demand. IFN Working Paper 1001, Research Institute of Industrial Economics.

Galindo-Rueda, F. and S. Pereira (2004). The impact of the National Minimum Wage on British firms. Final Report to the Low Pay Commission on the Econometric Evidence from the Annual Respondents Database.

Korkeamäki, O. (2011). The Finnish Payroll Tax Cut Experiment Revisited. Working Papers 22, Government Institute for Economic Research Finland (VATT).

Metcalf, D. (2008). Why has the British National Minimum Wage had Little or No Impact on Employment? Journal of Industrial Relations 50(3), 489-512.

Neumark, D. and W. Wascher (2006). Minimum Wages And Employment: A Review Of Evidence From The New Minimum Wage Research. NBER Working Papers 12663, National Bureau of Economic Research, Inc.

Schmitt, J. (2013). Why Does the Minimum Wage Have No Discernible Effect on Employment? CEPR Reports and Issue Briefs 2013-04, Center for Economic and Policy Research (CEPR).

Wadsworth, J. (2010). Did the National Minimum Wage Affect UK Prices? Fiscal Studies $31(1), 81-120$. 


\section{A Robustness results}

Table A.1: Operating profit by turnover (intention to treat, treatment intensity in 2005)

\begin{tabular}{|c|c|c|c|c|c|c|}
\hline & \multicolumn{3}{|c|}{ STAND-ALONE } & \multicolumn{3}{|c|}{ CORP. GROUPS } \\
\hline & $q=0.1$ & $q=0.5$ & $q=0.9$ & $q=0.1$ & $q=0.5$ & $q=0.9$ \\
\hline DD 2006 & $\begin{array}{c}-0.000 \\
(0.006)\end{array}$ & $\begin{array}{c}0.005 \\
(0.004)\end{array}$ & $\begin{array}{c}0.006 \\
(0.011)\end{array}$ & $\begin{array}{c}-0.005 \\
(0.075)\end{array}$ & $\begin{array}{c}0.032 \\
(0.032)\end{array}$ & $\begin{array}{c}-0.314 \\
(0.205)\end{array}$ \\
\hline DD 2007 & $\begin{array}{c}-0.001 \\
(0.006)\end{array}$ & $\begin{array}{c}0.002 \\
(0.004)\end{array}$ & $\begin{array}{c}0.000 \\
(0.011)\end{array}$ & $\begin{array}{c}0.052 \\
(0.075)\end{array}$ & $\begin{array}{c}0.067^{*} \\
(0.032)\end{array}$ & $\begin{array}{c}-0.174 \\
(0.206)\end{array}$ \\
\hline DD 2008 & $\begin{array}{c}-0.002 \\
(0.006)\end{array}$ & $\begin{array}{c}-0.002 \\
(0.004)\end{array}$ & $\begin{array}{c}-0.003 \\
(0.011)\end{array}$ & $\begin{array}{c}0.033 \\
(0.076)\end{array}$ & $\begin{array}{l}0.055 \\
(0.032)\end{array}$ & $\begin{array}{c}-0.180 \\
(0.209)\end{array}$ \\
\hline$R^{2}$ & 0.03 & 0.03 & 0.09 & 0.65 & 0.05 & 0.62 \\
\hline $\mathrm{N}$ & 32,419 & 32,419 & 32,419 & 20,563 & 20,563 & 20,563 \\
\hline$y_{q}$ & -0.018 & 0.035 & 0.142 & -0.031 & 0.045 & 0.180 \\
\hline
\end{tabular}

Notes: Pseudo- $R^{2}$ given for quantile regressions. $y_{q}$ gives the value of the outcome variable at quantile $q$.

Table A.2: Value added per full-time equivalent employee in thousands of SEK (intention to treat, treatment intensity in 2005)

\begin{tabular}{|c|c|c|c|c|c|c|}
\hline & \multicolumn{3}{|c|}{ StAND-ALOnE } & \multicolumn{3}{|c|}{ CORP. GROUPS } \\
\hline & $q=0.1$ & $q=0.5$ & $q=0.9$ & $q=0.1$ & $q=0.5$ & $q=0.9$ \\
\hline DD 2006 & $\begin{array}{l}-3.3 \\
(8.4)\end{array}$ & $\begin{array}{l}-0.9 \\
(7.2)\end{array}$ & $\begin{array}{c}-2.3 \\
(18.6)\end{array}$ & $\begin{array}{l}-22.1 \\
(35.0)\end{array}$ & $\begin{array}{l}-3.3 \\
(18.4)\end{array}$ & $\begin{array}{c}0.1 \\
(61.0)\end{array}$ \\
\hline DD 2007 & $\begin{array}{l}-8.4 \\
(8.5)\end{array}$ & $\begin{array}{l}-8.2 \\
(7.3)\end{array}$ & $\begin{array}{c}-29.4 \\
(18.9)\end{array}$ & $\begin{array}{c}-24.1 \\
(35.2)\end{array}$ & $\begin{array}{c}-26.6 \\
(18.5)\end{array}$ & $\begin{array}{c}2.1 \\
(61.4)\end{array}$ \\
\hline DD 2008 & $\begin{array}{l}-7.7 \\
(8.6)\end{array}$ & $\begin{array}{c}-17.5^{*} \\
(7.4)\end{array}$ & $\begin{array}{c}-56.9^{* *} \\
(19.2)\end{array}$ & $\begin{array}{l}-3.7 \\
(35.6)\end{array}$ & $\begin{array}{c}-11.4 \\
(18.7)\end{array}$ & $\begin{array}{l}-41.7 \\
(62.1)\end{array}$ \\
\hline$R^{2}$ & 0.15 & 0.24 & 0.24 & 0.07 & 0.17 & 0.20 \\
\hline $\mathrm{N}$ & 32,353 & 32,353 & 32,353 & 20,535 & 20,535 & 20,535 \\
\hline$y_{q}$ & 246.2 & 391.6 & 638.6 & 270.6 & 476.2 & 819.8 \\
\hline
\end{tabular}


Table A.3: Gross investments by turnover (intention to treat, treatment intensity in 2005)

\begin{tabular}{|c|c|c|c|c|c|c|}
\hline & \multicolumn{3}{|c|}{ StAND-ALONE } & \multicolumn{3}{|c|}{ Corp. Groups } \\
\hline & $q=0.1$ & $q=0.5$ & $q=0.9$ & $q=0.1$ & $q=0.5$ & $q=0.9$ \\
\hline DD 2006 & $\begin{array}{c}0.000 \\
(0.000)\end{array}$ & $\begin{array}{c}-0.000 \\
(0.003)\end{array}$ & $\begin{array}{c}0.010 \\
(0.017)\end{array}$ & $\begin{array}{c}-0.000 \\
(0.259)\end{array}$ & $\begin{array}{c}0.037 \\
(0.043)\end{array}$ & $\begin{array}{c}-0.375 \\
(0.267)\end{array}$ \\
\hline DD 2007 & $\begin{array}{c}0.000 \\
(0.000)\end{array}$ & $\begin{array}{c}-0.001 \\
(0.003)\end{array}$ & $\begin{array}{c}-0.002 \\
(0.017)\end{array}$ & $\begin{array}{c}0.003 \\
(0.260)\end{array}$ & $\begin{array}{c}0.002 \\
(0.044)\end{array}$ & $\begin{array}{c}-0.303 \\
(0.269)\end{array}$ \\
\hline DD 2008 & $\begin{array}{c}0.000 \\
(0.000)\end{array}$ & $\begin{array}{c}-0.001 \\
(0.003)\end{array}$ & $\begin{array}{c}0.003 \\
(0.018)\end{array}$ & $\begin{array}{c}0.002 \\
(0.263)\end{array}$ & $\begin{array}{c}0.022 \\
(0.044)\end{array}$ & $\begin{array}{c}-0.203 \\
(0.272)\end{array}$ \\
\hline$R^{2}$ & 0.00 & 0.06 & 0.19 & 0.00 & 0.08 & 0.72 \\
\hline $\mathrm{N}$ & 32,243 & 32,243 & 32,243 & 20,563 & 20,563 & 20,563 \\
\hline$y_{q}$ & 0.000 & 0.012 & 0.156 & 0.001 & 0.016 & 0.145 \\
\hline
\end{tabular}

Notes: Pseudo- $R^{2}$ given for quantile regressions. $y_{q}$ gives the value of the outcome variable at quantile $q$.

Table A.4: Verifying treatment definition: social fees per employee in thousands of SEK (intention to treat, treatment intensity in 2005)

\begin{tabular}{|c|c|c|c|c|c|c|}
\hline & \multicolumn{3}{|c|}{ STAND-ALONE } & \multicolumn{3}{|c|}{ CORP. GROUPS } \\
\hline & $q=0.1$ & $q=0.5$ & $q=0.9$ & $q=0.1$ & $q=0.5$ & $q=0.9$ \\
\hline DD 2006 & $\begin{array}{c}0.9 \\
(1.8)\end{array}$ & $\begin{array}{c}0.1 \\
(1.5)\end{array}$ & $\begin{array}{c}3.6 \\
(3.4)\end{array}$ & $\begin{array}{c}4.5 \\
(4.3)\end{array}$ & $\begin{array}{l}-1.0 \\
(3.7)\end{array}$ & $\begin{array}{l}-2.9 \\
(9.1)\end{array}$ \\
\hline DD 2007 & $\begin{array}{l}-2.4 \\
(1.8)\end{array}$ & $\begin{array}{c}-3.2^{*} \\
(1.6)\end{array}$ & $\begin{array}{l}-4.0 \\
(3.4)\end{array}$ & $\begin{array}{c}0.3 \\
(4.4)\end{array}$ & $\begin{array}{c}-8.6^{*} \\
(3.8)\end{array}$ & $\begin{array}{c}-14.8 \\
(9.2)\end{array}$ \\
\hline DD 2008 & $\begin{array}{c}-5.0^{* *} \\
(1.8)\end{array}$ & $\begin{array}{c}-6.2^{* * *} \\
(1.6)\end{array}$ & $\begin{array}{c}-6.4 \\
(3.5)\end{array}$ & $\begin{array}{l}-5.3 \\
(4.4)\end{array}$ & $\begin{array}{c}-10.5^{* *} \\
(3.8)\end{array}$ & $\begin{array}{c}-14.5 \\
(9.3)\end{array}$ \\
\hline$R^{2}$ & 0.18 & 0.25 & 0.28 & 0.19 & 0.27 & 0.32 \\
\hline $\mathrm{N}$ & 32,353 & 32,353 & 32,353 & 20,535 & 20,535 & 20,535 \\
\hline$y_{q}$ & 60.4 & 92.8 & 139.7 & 69.9 & 110.9 & 186.9 \\
\hline
\end{tabular}

Notes: Pseudo- $R^{2}$ given for quantile regressions. $y_{q}$ gives the value of the outcome variable at quantile $q$. 